\title{
Effects of laparoscopic radical gastrectomy and the influence on immune function and inflammatory factors
}

\author{
ZHAO MA, XUEBIN BAO and JUNBAO GU
}

Department of Gastrointestinal Surgery, The People's Hospital of Zhengzhou University, Zhengzhou, Henan 450003, P.R. China

Received February 17, 2016; Accepted May 23, 2016

DOI: $10.3892 /$ etm.2016.3404

\begin{abstract}
The effects of laparoscopic radical gastrectomy were observed, and changes in immune function and inflammatory factors of gastric cancer patients were examined. In total, 236 cases of laparoscopic radical gastrectomy were selected between March 2014 and October 2015 and divided into the control and experimental groups. The control group was treated using open radical gastrectomy, while laparoscopic radical gastrectomy was used in the experimental group. Treatment effects, immune function and inflammatory factor in the two groups were compared. Compared to the open radical gastrectomy group, surgery time in the laparoscopic radical gastrectomy group was longer, while blood loss during operation, time of exsufflation through anus after operation, duration of acesodyne use, length of stay and incidence of complications were lower, and the differences were statistically significant $(\mathrm{P}<0.05)$. As for the amount of lymph node dissection, differences between the two groups were of no statistical significance $(\mathrm{P}>0.05)$. $\mathrm{CD}^{+}, \mathrm{CD}^{+}$ and $\mathrm{CD}^{+} / \mathrm{CD}^{+}$cell ratios in the two groups 1 and 7 days after surgery were obviously lower than those before surgery $(\mathrm{P}<0.05)$ while $\mathrm{CD}^{+}$was higher. In addition, compared with the open radical gastrectomy group, $\mathrm{CD}^{+}, \mathrm{CD}^{+}, \mathrm{CD}^{+} /$ $\mathrm{CD}^{+}$cell ratios in the laparoscopic radical gastrectomy group increased while CD8 was lower, and differences were statistically significant $(\mathrm{P}<0.05)$. Differences of interleukin (IL)-6, tumor necrosis factor (TNF) and CRP between the two groups 1 day before surgery were of no statistical significance $(\mathrm{P}>0.05)$. One day after surgery, IL-6, TNF and CRP in the two groups increased $(\mathrm{P}<0.05)$ and the values in the open radical gastrectomy group were higher $(\mathrm{P}<0.05)$. Differences in IL- 6 between the two groups 7 days after surgery were of no statistical significance $(\mathrm{P}>0.05)$. However, for $\mathrm{CRP}$ and TNF, the two values gradually decreased and the differences
\end{abstract}

Correspondence to: Dr Xuebin Bao, Department of Gastrointestinal Surgery, The People's Hospital of Zhengzhou University, 7 Weiwu Road, Zhengzhou, Henan 450003, P.R. China

E-mail: cxls4318926@163.com

Key words: gastric cancer, laparoscopic radical gastrectomy, open radical gastrectomy, immune function, inflammatory factor between the groups were of statistical significance $(\mathrm{P}<0.05)$. In conclusion, laparoscopic radical gastrectomy has better treatment effects, lower inflammatory response, less impact on the immune system and fewer complications, which is worth clinical consideration.

\section{Introduction}

Gastric cancer (GC) is the second leading cause of mortality and the fourth most common cancer in the world (1). GC has a high prevalence in Asian countries, including China (2). Currently, surgery is the only treatment approach. However, two thirds of patients present with inoperable locally advanced or metastatic disease at diagnosis as well as local and distant recurrence after curative gastrectomy (3). In addition, combinatorial chemotherapy, which remains the mainstream treatment for these patients, is associated with poor prognosis (5-year survival rate of $<10 \%$ ) (4). Although a number of novel targeted therapeutics for gastric cancer have been identified (5-7), successful treatment is scarce and novel forms of treatment strategies are being intensively investigated.

Since the seminal application of laparoscopic radical gastrectomy in patients with advanced gastric cancer in 1991 (8), laparoscopic radical gastrectomy has been increasingly used as a promising approach, although laparoscopic radical gastrectomy is technically demanding and requires a long learning curve (9). As a minimally invasive surgery, laparoscopic radical gastrectomy has advantages such as small incisions, less trauma, bleeding and complications $(8,9)$.

In the present study, the clinical effects of laparoscopic radical gastrectomy were observed to examine its influences on immune function and inflammatory factors. The results showed that laparoscopic radical gastrectomy has better treatment effects, lower inflammatory response, less impact on the immune system and fewer complications.

\section{Materials and methods}

Materials. A total of 236 cases of gastric cancer patients received radical gastrectomy in the People's Hospital of Zhengzhou University (Henan, China) between March 2014 and October 2015. The patients included 148 men and 88 women, with an age range of 30-72 years and an average age of $51.32 \pm 14.40$ years. Tumor location included 59 cases in the gastric region, 97 cases in the gastric antrum, 30 cases in 
Table I. Comparison of patients in two groups after surgery.

\begin{tabular}{|c|c|c|c|c|c|c|c|c|}
\hline Group & Cases & $\begin{array}{c}\text { Surgery } \\
\text { time (min) }\end{array}$ & $\begin{array}{c}\text { Blood loss } \\
\text { during surgery } \\
(\mathrm{ml})\end{array}$ & $\begin{array}{c}\text { Exsufflation } \\
\text { through anus } \\
\text { after surgery (h) }\end{array}$ & $\begin{array}{l}\text { Lymph node } \\
\text { dissection } \\
\text { (piece) }\end{array}$ & $\begin{array}{l}\text { Acesodyne } \\
\text { used (days) }\end{array}$ & $\begin{array}{l}\text { Length } \\
\text { of stay } \\
\text { (days) }\end{array}$ & $\begin{array}{l}\text { Incidence rate of } \\
\text { complications (\%) }\end{array}$ \\
\hline $\begin{array}{l}\text { Laparoscopic } \\
\text { radical } \\
\text { gastrectomy } \\
\text { group }\end{array}$ & 129 & $232.56 \pm 45.62^{\mathrm{a}}$ & $188.86 \pm 78.33^{\mathrm{a}}$ & $13.8 \pm 1.5^{\mathrm{a}}$ & $21.34 \pm 7.56^{\mathrm{b}}$ & $2.7 \pm 0.7^{\mathrm{a}}$ & $12.1 \pm 1.8^{\mathrm{a}}$ & $13^{\mathrm{a}}$ \\
\hline $\begin{array}{l}\text { Open radical } \\
\text { gastrectomy } \\
\text { group }\end{array}$ & 107 & $182.34 \pm 47.62$ & $318.26 \pm 82.34$ & $23.6 \pm 5.4$ & $22.66 \pm 8.72$ & $5.6 \pm 1.1$ & $15.2 \pm 2.3$ & 27 \\
\hline $\mathrm{T} / \chi^{2}$-value & - & 6.345 & 23.457 & 3.231 & 1.124 & 13.627 & 2.236 & 4.634 \\
\hline P-value & - & 0.0004 & 0.0003 & 0.0004 & 0.163 & 0.0004 & 0.0001 & 0.00003 \\
\hline
\end{tabular}

Compared with open radical gastrectomy group, ${ }^{\mathrm{a}} \mathrm{P}<0.05$, ${ }^{\mathrm{b}} \mathrm{P}>0.05$

the junction of the gastric region and gastric antrum, 23 cases in the stomach incisura and 27 cases at the bottom of the cardiac stomach. All the patients received gastrointestinal barium meal, endoscopy and abdominal CT examination prior to surgery to confirm pathology. Chest X-ray and ultrasonic testing were performed to ascertain whether there were liver metastases or metastatic sites. Patients were randomly divided into the laparoscopic radical gastrectomy (129 cases) and open radical gastrectomy groups (107 cases). Differences between the two groups in terms of age, gender, body mass index, tumor location and TNM pathological stage were of no statistical significance $(P>0.05)$.

Surgery. The 236 patients received general anesthesia and intubation prior to surgery. Open radical gastrectomy was performed on the control group while laparoscopic radical gastrectomy was used on the experimental group. In the experimental group, after umbilical puncture, $\mathrm{CO}_{2}$ pneumoperitoneum was established with intra-abdominal pressure maintained at 13-14 mmHg. Punctures were created $12 \mathrm{~mm}$ below the costal margin of the left anterior axillary line, $5 \mathrm{~cm}$ left of the navel, $5 \mathrm{~mm}$ below the costal margin of the right anterior axillary line and $12 \mathrm{~mm}$ upper of the right mid-clavicular line to position a sheathed needle and laparoscopic camera lens for exploration of the abdomen. This assessment determined whether the tumor metastasized onto organs and peripheral viscera. Proximal subtotal gastrectomy or distal gastrectomy was then selected based on patient findings. Symptomatic and supportive treatments such as routine disinfection were performed after surgery.

Observation index and testing method. Immune function indices such as interleukin (IL)-6, tumor necrosis factor (TNF), CRP, $\mathrm{CD}^{+}, \mathrm{CD}^{+}, \mathrm{CD}^{+}$and $\mathrm{NK}$ were tested in the two groups after surgery. Enzyme-linked immunosorbent assay was used to test IL-6 and TNF. CRP was tested using the immune suspension method. $\mathrm{CD}^{+}, \mathrm{CD}^{+}$and $\mathrm{CD} 8^{+}$cells were tested using FACScan flow cytometry (BD Biosciences, Franklin Lakes, NJ, USA). Furthermore, surgery time, blood loss during operation, amount of lymph node dissection, time of exsufflation through anus after operation, duration of acesodyne use, length of stay and incidence of complications in the two groups were observed and compared.

Statistical analysis. SPSS 19.0 statistical software (SPSS software Inc. (Chicago, IL, USA) was used for statistical analysis. Data were shown as mean \pm standard deviation. Comparisons were made using the $t$-test. The $\chi^{2}$ test was used for enumeration data. $\mathrm{P}<0.05$ was considered statistically significant.

\section{Results}

Comparison of patients in the two groups after surgery. Compared with the open radical gastrectomy group, surgery time in the laparoscopic radical gastrectomy group was longer while blood loss during the operation, time of exsufflation through anus after operation, duration of acesodyne use, length of stay and incidence of complications were obviously lower, and the differences were statistically significant $(\mathrm{P}<0.05)$. There were no obvious differences between the two groups regarding the amount of lymph node dissection, which was of no statistical significance $(\mathrm{P}>0.05)$ (Table I).

Changes of IL-6, TNF and CRP in two groups before and after surgery. Differences of IL-6, TNF and CRP in two groups 1 day prior to surgery were of no statistical significance $(\mathrm{P}>0.05)$. One day after surgery, IL-6, TNF and CRP in the two groups were increased $(\mathrm{P}<0.05)$ and the values in open radical gastrectomy group were higher $(\mathrm{P}<0.05)$. Differences of IL-6 in the two groups 7 days after surgery were of no statistical significance $(\mathrm{P}>0.05)$, but $\mathrm{CRP}$ and TNF values decreased gradually and their differences in the two groups were of statistical significance $(\mathrm{P}<0.05)$ (Table II).

Comparison of immune cell testing results in the two groups. $\mathrm{CD}^{+}, \mathrm{CD}^{+}$and $\mathrm{CD} 4^{+} / \mathrm{CD}^{+}$cell ratios in the two groups 1 and 7 days after surgery were obviously lower than those prior to surgery $(\mathrm{P}<0.05)$ while $\mathrm{CD} 8^{+}$was higher. In addition, compared with the other groups, $\mathrm{CD}^{+}, \mathrm{CD}^{+}, \mathrm{CD}^{+} /$ $\mathrm{CD}^{+}$cell ratios in laparoscopic radical gastrectomy group were increased while CD8 was lower, and differences were of statistical significance $(\mathrm{P}<0.05)$ (Table III). 
Table II. Changes of IL-6, TNF and CRP in the two groups before and after surgery.

\begin{tabular}{|c|c|c|c|c|c|}
\hline Group & Cases & Time & IL-6 (ng/l) & $\mathrm{CRP}(\mathrm{ng} / \mathrm{l})$ & TNF (ng/l) \\
\hline \multirow{3}{*}{$\begin{array}{l}\text { Laparoscopic radical } \\
\text { gastrectomy group }\end{array}$} & \multirow[t]{3}{*}{129} & Before surgery & $8.2 \pm 2.3$ & $12.4 \pm 2.1$ & $7.68 \pm 0.25$ \\
\hline & & 1 day after surgery & $18.3 \pm 4.6^{\mathrm{a}, \mathrm{b}}$ & $27.8 \pm 3.5^{\mathrm{a}, \mathrm{b}}$ & $12.79 \pm 0.13^{\mathrm{a}, \mathrm{b}}$ \\
\hline & & 7 days after surgery & $10.7 \pm 3.4^{\mathrm{b}}$ & $11.5 \pm 2.9^{\mathrm{a}}$ & $7.48 \pm 0.23^{\mathrm{a}}$ \\
\hline \multirow{3}{*}{$\begin{array}{l}\text { Open radical } \\
\text { gastrectomy group }\end{array}$} & \multirow[t]{3}{*}{107} & Before surgery & $8.1 \pm 2.1$ & $12.2 \pm 2.2$ & $8.11 \pm 0.33$ \\
\hline & & 1 day after surgery & $42.6 \pm 7.4^{\mathrm{b}}$ & $38.4 \pm 5.7^{\mathrm{b}}$ & $18.21 \pm 0.26$ \\
\hline & & 7 days after surgery & $11.5 \pm 3.5^{\mathrm{b}}$ & $19.6 \pm 4.5^{\mathrm{b}}$ & $10.35 \pm 0.30^{\mathrm{b}}$ \\
\hline
\end{tabular}

Compared with open radical gastrectomy group, ${ }^{\mathrm{a}} \mathrm{P}<0.05$; compared with before surgery, ${ }^{\mathrm{b}} \mathrm{P}<0.05$. IL, interleukin; $\mathrm{TNF}$, tumor necrosis factor.

Table III. Comparison of immune cell testing results in the two groups.

\begin{tabular}{lclllll}
\hline Group & Cases & \multicolumn{1}{c}{ Time } & $\mathrm{CD}^{+}(\%)$ & $\mathrm{CD}^{+}(\%)$ & $\mathrm{CD}^{+}(\%)$ & $\mathrm{CD}^{+} / \mathrm{CD} 8^{+}(\%)$ \\
\hline Laparoscopic radical & \multirow{2}{*}{129} & Before surgery & $61.25 \pm 3.47$ & $31.84 \pm 2.23$ & $26.56 \pm 0.65$ & $1.23 \pm 0.12$ \\
gastrectomy group & & 1 day after surgery & $54.35 \pm 3.38^{\mathrm{a}, \mathrm{b}}$ & $27.85 \pm 3.13^{\mathrm{a}, \mathrm{b}}$ & $27.86 \pm 0.52^{\mathrm{a}, \mathrm{b}}$ & $0.98 \pm 0.07^{\mathrm{a}, \mathrm{b}}$ \\
& & 7 days after surgery & $58.69 \pm 3.14^{\mathrm{a}, \mathrm{b}}$ & $29.25 \pm 3.24^{\mathrm{a}, \mathrm{b}}$ & $27.21 \pm 0.33^{\mathrm{a}, \mathrm{b}}$ & $1.18 \pm 0.15^{\mathrm{a}, \mathrm{b}}$ \\
Open radical & \multirow{2}{*}{107} & Before surgery & $61.32 \pm 3.34$ & $31.78 \pm 2.33$ & $26.57 \pm 0.74$ & $1.22 \pm 0.11$ \\
gastrectomy group & & 1 day after surgery & $50.12 \pm 3.32^{\mathrm{a}}$ & $24.47 \pm 2.62^{\mathrm{a}}$ & $29.93 \pm 0.25^{\mathrm{a}}$ & $0.76 \pm 0.05^{\mathrm{a}}$ \\
& & 7 days after surgery & $51.31 \pm 2.88^{\mathrm{a}}$ & $27.06 \pm 2.68^{\mathrm{a}}$ & $28.85 \pm 0.26^{\mathrm{a}}$ & $0.85 \pm 0.06^{\mathrm{a}}$
\end{tabular}

Compared with before surgery, ${ }^{\mathrm{a}} \mathrm{P}<0.05$; compared with open radical gastrectomy group, ${ }^{\mathrm{b}} \mathrm{P}<0.05$.

\section{Discussion}

Currently, it is believed that laparoscopic radical gastrectomy is notable for minimal trauma and quick recovery after surgery (10-12). In the present study, when the open radical gastrectomy group was compared with patients undergoing laparoscopic radical gastrectomy, the latter group required more surgical time, but was associated with less blood loss during the operation, which supported a rapid recovery. Surgical wounds activate inflammatory reactions through a series of responses, causing the release of inflammatory mediators, which contributes to negative treatment outcomes. Inflammatory responses are stronger with larger wounds. Compared with the open radical gastrectomy group, the anus exhausting time of patients in the laparoscopic group was shorter, thus the laparoscopic radical gastrectomy contributed to more rapid patient recovery. Analgesia duration, length of stay and complication rates of patients in the laparoscopic radical gastrectomy group were less, indicating that laparoscopic radical gastrectomy assists in more rapid patient recovery and reduction of complication rates.

As a major acute reactive protein obtained by synthesis of IL-6, CRP is an important acute inflammatory mediator. CRP, IL-6 and TNF levels are commonly used in indexes in studying stress response $(13,14)$. Stress response is closely related to immune function. Immunosuppression is caused because of prolonged stress state or excessive stress, while relapse and metastasis of malignant tumor after surgery are closely related to immune status. Comparisons between open and laparoscopic radical gastrectomy regarding the degree of trauma and stress contribute to a better understanding of their influence on immune states and provide a theoretical foundation for selecting the best surgical treatment for gastric cancer. In the present study, differences of IL-6, TNF and CRP in the two groups 1 day before surgery were of no statistical significance $(\mathrm{P}>0.05)$. One day after surgery, IL-6, TNF and CRP in the two groups were increased $(\mathrm{P}<0.05)$ and the values in open radical gastrectomy group were higher $(\mathrm{P}<0.05)$. Differences of IL- 6 between the two groups 7 days after surgery were of no statistical significance $(\mathrm{P}>0.05)$, but $\mathrm{CRP}$ and TNF values decreased slowly and the differences in the two groups were statistically significant $(\mathrm{P}<0.05)$. The abovementioned values were increased significantly in the two groups due to trauma caused by surgery. However, those indexes in the laparoscopic radical gastrectomy group after surgery were lower than the other group and the patients recovered faster. Therefore, it can be concluded that laparoscopic radical gastrectomy is shown to minimize trauma, stress response and accelerate recovery after surgery. One possible reason is that laparoscopic surgery causes less tissue damage and has a lower rate of infection, therefore, with less impact on global physiological function.

As a minimally invasive surgery, laparoscopic surgery has its own advantages, but may cause certain stress responses, influencing immune function $(15,16)$. During surgical treatment for gastric cancer patients, analysis on immune functions before and after surgery may reflect indirectly the relationship that trauma in surgery has with immunological function repression. The immune response of an organism to tumor is mainly mediated by $\mathrm{T}$ cells. T-cell subsets such as $\mathrm{CD}^{+}, \mathrm{CD}^{+}, \mathrm{CD}^{+}$ and $\mathrm{CD}^{+} / \mathrm{CD}^{+}$are able to directly reflect immune functions of gastric cancer patients after surgery (6). $\mathrm{CD}^{+}$is a peripheral mature $\mathrm{T}$ lymphocyte that can assist TCR in recognizing MHC $(17,18)$ on APC. D4 ${ }^{+}$is a helper and inducer T cell, that may release a large amount of cytokines after being activated 
and help increase antitumor effects. $\mathrm{CD}^{+}$is also known as a cytotoxic $\mathrm{T}$ cell and is capable of cleaning viruses and adhesions $(19,20)$. CD4 $/$ CD8 can reflect the immune balance of an organism, if the ratio is low, it means that body immune function is decreasing and may increase tumor proliferation. Of note, a low ratio is commonly regarded as the index for severe disease or a poor prognosis (21-23). In the present study, $\mathrm{CD}^{+}$, $\mathrm{CD}^{+}$and $\mathrm{CD}^{+} / \mathrm{CD}^{+}$cell ratios in two groups 1 and 7 days after surgery were obviously lower than those before surgery $(\mathrm{P}<0.05)$ while $\mathrm{CD}^{+}$was higher. In addition, compared with the other group, $\mathrm{CD}^{+}, \mathrm{CD} 4^{+}, \mathrm{CD}^{+} / \mathrm{CD}^{+}$cell ratios in the laparoscopic radical gastrectomy group were increased while CD8 was lower with the differences being of statistical significance $(\mathrm{P}<0.05)$. This also demonstrates that laparoscopic surgery produces less trauma and impact on immune functions, which is good for recovery after surgery and has a high clinical reference value.

In conclusion, compared with the open radical gastrectomy group, there is less trauma and change on immune function and inflammatory response in the laparoscopic radical gastrectomy group, which promotes good recovery. Therefore, it is believed that laparoscopic surgery is a safe, reliable and feasible surgery worth clinical consideration.

\section{References}

1. Jemal A, Bray F, Center MM, Ferlay J, Ward E and Forman D: Global cancer statistics. CA Cancer J Clin 61: 69-90, 2011.

2. Shin A, Kim J and Park S: Gastric cancer epidemiology in Korea. J Gastric Cancer 11: 135-140, 2011.

3. Bilici A, Selcukbiricik F, Demir N, Oven Ustaalioglu BB, Dikilitas $\mathrm{M}$ and Yildiz O: Modified docetaxel and cisplatin in combination with capecitabine (DCX) as a first-line treatment in HER2- negative advanced gastric cancer. Asian Pac J Cancer Prev 15: 8661-8666, 2014.

4. Liu J, Qu XJ, Xu L, Zang Y, Qu JL, Hou KZ and Liu YP: Bortezomib synergizes TRAIL-induced apoptosis in gastric cancer cells. Dig Dis Sci 55: 3361-3368, 2010.

5. Smyth EC and Cunningham D: Targeted therapy for gastric cancer. Current treatment options in oncology 13: 377-389, 2012.

6. Wong $\mathrm{H}$ and Yau T: Molecular targeted therapies in advanced gastric cancer: does tumor histology matter? Therap Adv Gastroenterol 6: 15-31, 2013.

7. Nadauld LD and Ford JM: Molecular profiling of gastric cancer: toward personalized cancer medicine. J Clin Oncol 31: 838-839, 2013.

8. Huang CM, Lin JX, Zheng CH, Li P, Xie JW, Wang JB, Lu J and Chen QY: Clinical efficacy analysis of laparoscopy-assisted radical gastrectomy for 1380 patients with gastric cancer. Zhonghua Wei Chang Wai Ke Za Zhi 15: 1265-1268, 2012 (In Chinese).

9. Yoshimura F, Inaba K, Kawamura Y, Ishida Y, Taniguchi K, Isogaki J, Satoh S, Kanaya S, Sakurai Y and Uyama I: Clinical outcome and clinicopathological characteristics of recurrence after laparoscopic gastrectomy for advanced gastric cancer. Digestion 83: 184-190, 2011.
10. Wang DR, Zhao JG, Yu HF, Wang LH, Jiang GQ, Li YK and Chen J: Laparoscopic versus open surgery for D2 gastrectomy in advanced gastric cancer. Zhonghua Wei Chang Wai Ke Za Zhi 15: 964-966, 2012 (In Chinese).

11. Huang Z, Li G, Xu Y, Wang G and You S: Comparison of laparoscope-assisted D2 radical total gastrectomy and open gastrectomy for gastric cancer. Zhonghua Wei Chang Wai Ke Za Zhi 17: 781-784, 2014 (In Chinese).

12. Gong J, Cao Y, Wang Y, Zhang G, Wang P and Luo G: Three-step hand-assisted laparoscopic d2 radical gastrectomy for Chinese obese patients: A highly efficient and feasible surgical approach. J Cancer 6: 120-127, 2015.

13. Wang Y, Liu R, Zhang Z, Xue Q, Yan J, Yu J, Liu H, Zhao L, Mou T, Deng H, et al: A safety study of transumbilical single incision versus conventional laparoscopic surgery for colorectal cancer: study protocol for a randomized controlled trial. Trials 16: 539, 2015.

14. Cui M, Gong C, Jiang B, Yao Z, Chen L, Di J, Xing J, Yang H, Zhang C, Zhang N, et al: Evaluation of immune responses of gastric cancer patients treated by laparoscopic and open gastrectomy. Med Oncol 32: 253, 2015.

15. Hu Y, Zhao G and Zheng H: Therapeutic effects of laparotomy and laparoscopic surgery on patients with gastric cancer. Pak J Med Sci 31: 572-575, 2015.

16. Zhao HQ, Liu HR, Xiao L, Zheng F and Li WM: Laparoscopic cholecystectomy in elderly patients: an evaluation of immunity. Aging Clin Exp Res 27: 927-933, 2015.

17. Chang TC, Chen CC, Wang MY, Yang CY and Lin MT: Gasless laparoscopy-assisted distal gastrectomy for early gastric cancer: analysis of initial results. J Laparoendosc Adv Surg Tech A 21: 215-220, 2011.

18. Louis-Dit-Sully C, Blumenthal B, Duchniewicz M, Beck-Garcia K, Fiala GJ, Beck-García E, Mukenhirn M, Minguet S and Schamel WW: Activation of the TCR complex by peptide-MHC and superantigens. EXS 104: 9-23, 2014.

19. Larsen SK. Cellular immune responses towards regulatory cells. Dan Med J 63: pii: B5188, 2016.

20. Brentville VA, Metheringham RL, Gunn B, Symonds P, Daniels I, Gijon M, Cook K, Xue W and Durrant LG: Citrullinated vimentin presented on MHC-II in tumor cells is a target for CD4 T cell-mediated antitumor immunity. Cancer Res 76: 548-560, 2016.

21. Jackute J, Žemaitis M, Pranys D, Šitkauskienė B, Miliauskas S, Bajoriūnas V and Sakalauskas R: Distribution of CD4(+) and CD8(+) T cells in tumor islets and stroma from patients with non-small cell lung cancer in association with COPD and smoking. Medicina (Kaunas) 51: 263-271, 2015.

22. Jackute J, Zemaitis M, Pranys D, Sitkauskiene B, Miliauskas S, Bajoriunas V, Lavinskiene S and Sakalauskas R: The prognostic influence of tumor infiltrating Foxp3(+)CD4(+), CD4(+) and CD8(+) T cells in resected non-small cell lung cancer. J Inflamm (Lond) 12: 63, 2015.

23. Chen M, Mohtize M, Matteï MF, Villemot JP, Kohler C, Faure GC, Béné MC and de Carvalho Bittencourt M: Reduced levels of both circulating $\mathrm{CD}^{+}{ }^{+} \mathrm{CD} 25^{+} \mathrm{CD} 127$ (low/neg) and $\mathrm{CD}^{+} \mathrm{CD} 8$ (neg) invariant natural killer regulatory $\mathrm{T}$ cells in stable heart transplant recipients. Clin Exp Immunol 163: 104-112, 2011. 